\title{
ANATOMICAL STRUCTURE OF POLYGONATUM MILL. SPECIES IN THE PRECARPATHIAN REGION
}

\author{
NADIA RIZNYCHUK, VICTORIA GNIEZDILOVA
}

\begin{abstract}
Polygonatum Mill. species are found in woods of the temperate zone of the Northern Hemisphere. There are four species growing in Ukraine, the most common of which is Polygonatum multiflorum (L.) All. In forest and shrub habitats are also widespread Polygonatum odoratum (Mill.) Druce., Polygonatum latifolium Desf. and Polygonatum verticillatum (L.) All. Polygonatum species have rhizomes of the sympodial type. They are of a primary anatomical structure. In the primary growth of the stem, as well as rhizomes, there is the central cylinder (stele) and the cortex. The structure of the leaf blade is related to the performance of basic functions: photosynthesis, respiration and transpiration. The leaves are isolateral with a lighter adaxial and shaded abaxial sides. The leaf is covered with epidermis. Beneath the epidermis is chlorenchyma, which makes up the leaf pulp mesophyll.

The microscopic structure of Polygonatum multiflorum (L.) All. was studied. The anatomic description includes the characteristic of rhizomes, leaves and stems structure.
\end{abstract}

Keywords: anatomy, Polygonatum Mill., rhizome, stem, leaf.

\section{INTRODUCTION}

The genus Polygonatum Mill. belongs to the class Monocotyledons (Liliopsida), subclass Liliidae [1, p.72]. Nechitaylo V.A. and Kucheryava L.F. [2, p. 44] include the genus Polygonatum Mill. to the family Convallarriaceae of the order Asparagales. According to Morozyuk S.S. and Protopopova V.V. genus Polygonatum Mill. belongs to the family Asparagaceae, order Asparagales [3, p. 141]. According to the "Opredelitel...", the Solomon's seal is a representative of the Liliaceae family, the order Liliales [4, p. 243; 5, p. 68]. The alternative approach to the systematics of Polygonatum Mill. species offers phylogenetic system of angiosperms APG IV system (Angiosperm Phylogeny Group classification for the orders and families of flowering plants). According to this system, as well as data from The Plant List species the genus Polygonatum Mill. belongs to the family Asparagaceae, order Asparagales and class Monocotyledons [6, 7].

Polygonatum Mill. species are found in woods of the temperate zone of the Northern Hemisphere. They grow in oak, beech, mixed forests of the Caucasus, the Far East, the oakeries of Europe. This species is quite common in the Himalayas, Asia, Altai, Eastern Siberia, Central Europe [8, p.117; 9, p. 21;10, p. 801]. 
The representatives of the genus Polygonatum are perennial herbs with horizontal, brush-shaped rhizomes, which bear traces (rounded scars) of dead stems. The leaves are alternate or arranged in rings. The white, drooping, tubular fragrant hermaphrodite flowers grow singly or in pairs from the leaf axils. Perianth is tubular fused, greenish-white or pink, with six teeth. There are six stamens, they are shorter than the perianth. The fruit is a dark-blue berry.

There are four species growing in Ukraine, the most common of which is Polygonatum multiflorum (L.) All. In forest and shrub habitats are also widespread Polygonatum odoratum (Mill.) Druce., Polygonatum latifolium Desf. And Polygonatum verticillatum (L.) All. [11, p. 280].

Polygonatum multiflorum (L.) All. - perennial herb $30-60 \mathrm{~cm}$ tall. The horizontal rhizome is located in the soil. There are scars-stripes from underdeveloped scaly leaves and round scars from dead stems on the rhizome. The stem is glabrous, rounded, leaves are oblong or elliptical, slightly narrowed at the base, glabrous, with short petioles, green above and grayish-green below, $10-11 \mathrm{~cm}$ long and $4-4.5 \mathrm{~cm}$ wide. Flower stalks are in leaf axils. Flowers are in clusters of three to five. They are bell-shaped, glabrous, with white perianth, narrowed above the pharynx, slightly dilated at the top. Perianth has six greenish teeth, curved at the ends and short-haired inside. The fruit is a blue-black berry about $1 \mathrm{~cm}$ wide. Flowering time is from May to June. It occurs in shady mixed woods, shrubs in temperate zones, lower and middle mountain belts of Europe, the Caucasus, Asia Minor, the Himalayas and East Asia. In Ukraine it is found in the Carpathians, Polissya, forest-steppe regions, occasionally in the steppe and Crimea mountainous.

\section{RESULTS}

\subsection{Anatomical Structure of the Rhizome of Polygonatum Species}

Species of the genus Polygonatum have rhizomes of the sympodial type. They are formed by a sprouting underground shoot. At the same time, an apical bud is laid on the shoot, which grows upwards, reaches the soil surface and develops into an aerial part. A new underground shoot is formed from the nearest lateral bud.

Polygonatum species have rhizomes of a primary anatomical structure. Its peculiarity is that it distinguishes two clearly demarcated parts: the primary cortex and the central (vascular) cylinder. In the soil, the rhizome is located horizontally. It shows scars-streaks from underdeveloped scaly leaves and round scars from dead stems. The function of the integumentary tissue is performed by a singlelayer epiblem (Fig. 1), which is formed from dermatogen and consists of cells with thin cellulose membranes and outgrowths that significantly exceed the length of cells and form root hairs [14, p. 63].

The cortex is under the epidermis. It is divided into exodermis, mesodermis and endodermis. The exodermis (Fig. 2) performs protective, supporting and permeable functions.It consists of 3-5 layers of large, tightly closed cells of polygonal shape with thickened walls. Some of these cells are thin-walled, and others - with partially crusted walls. The mesodermis is a multilayered storage part of the cortex, which is represented by the ground tissue. It performs transport and sometimes air functions. Species of the genus Polygonatum Mill. have alive, large, round, loose mesodermis cells with thickened walls. They are filled with simple eccentric starch grains, which belong to ergastic substances [14, p. 63]. 


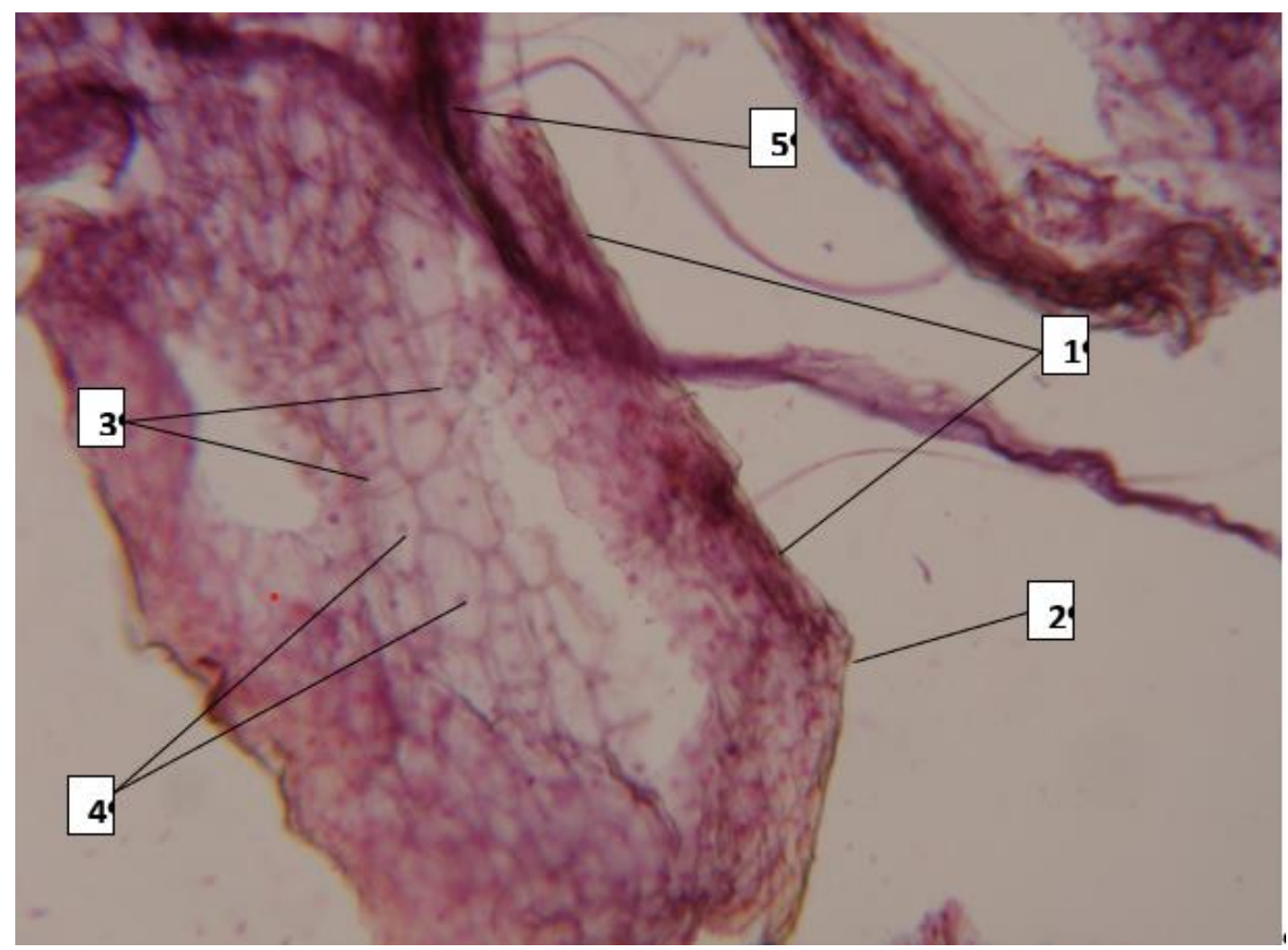

Fig. 1. Rhizome structure of Polygonatum multiflorum (L.) All. (Microphoto. Mag.: $x$ 1000): 1 -cuticle; 2 - epiblem; 3 - mesenchyme; 4 - simple eccentric starch grain; 5 - cortex.

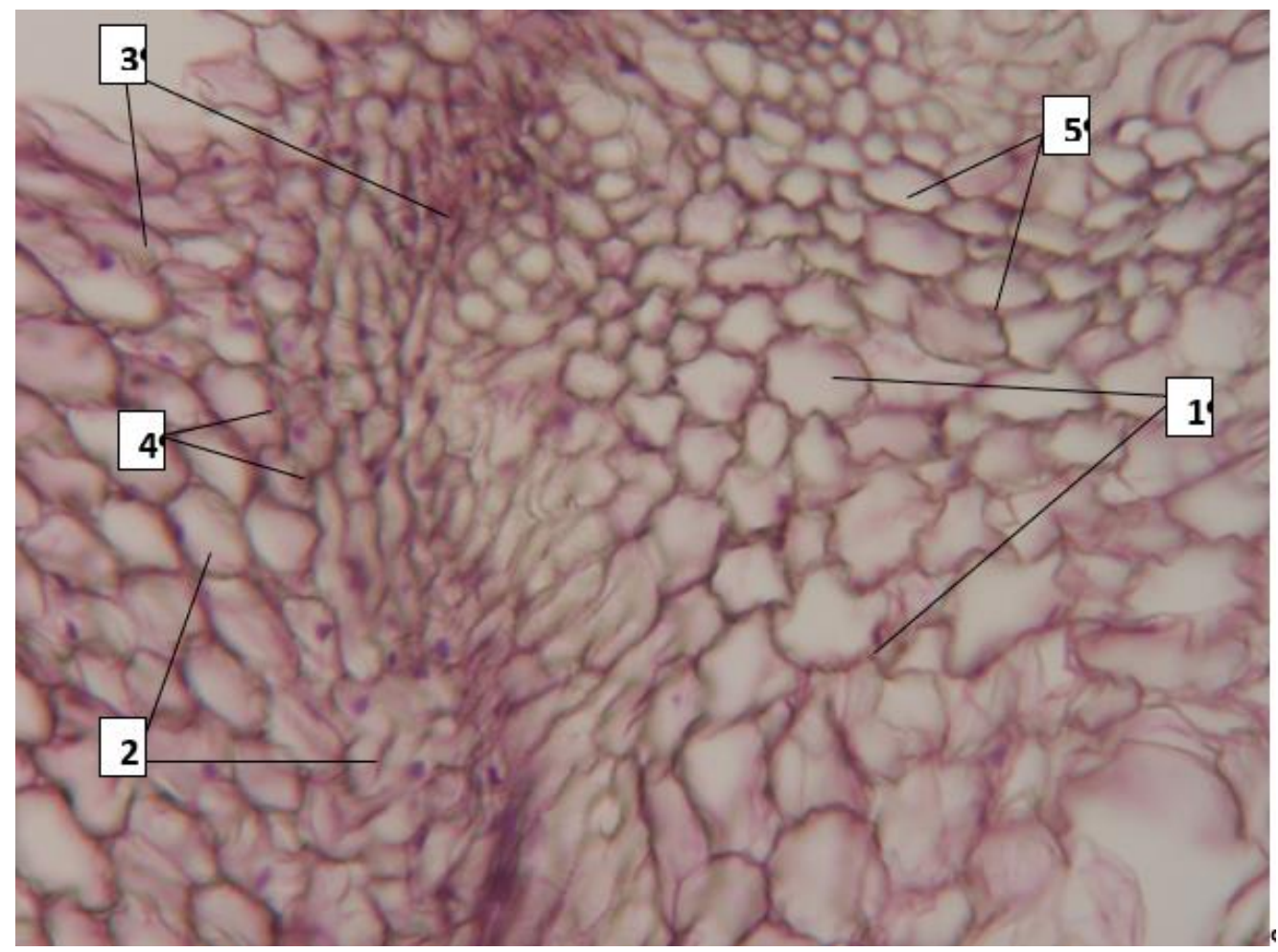

Fig. 2. Exodermis and mesodermis of Polygonatum multiflorum (L.) All . (Microphoto. Mag.: $x$ 1000): 1 - exodermis; 2 - mesodermis; 3 - simple eccentric starch grain; 4 - thickened mesodermis membrane; 5 - cortical wall of the exodermis. 
These starch grains are formed by forming a center of starch formation and layering around it dense dark - day and flooded light - night layers of starch, which are surrounded by an amyloplast membrane. Starch grain in its structure is simple (with one center of starch formation), and eccentric (with a shifted center of starch formation) (Fig. 3) [15, p. 181].

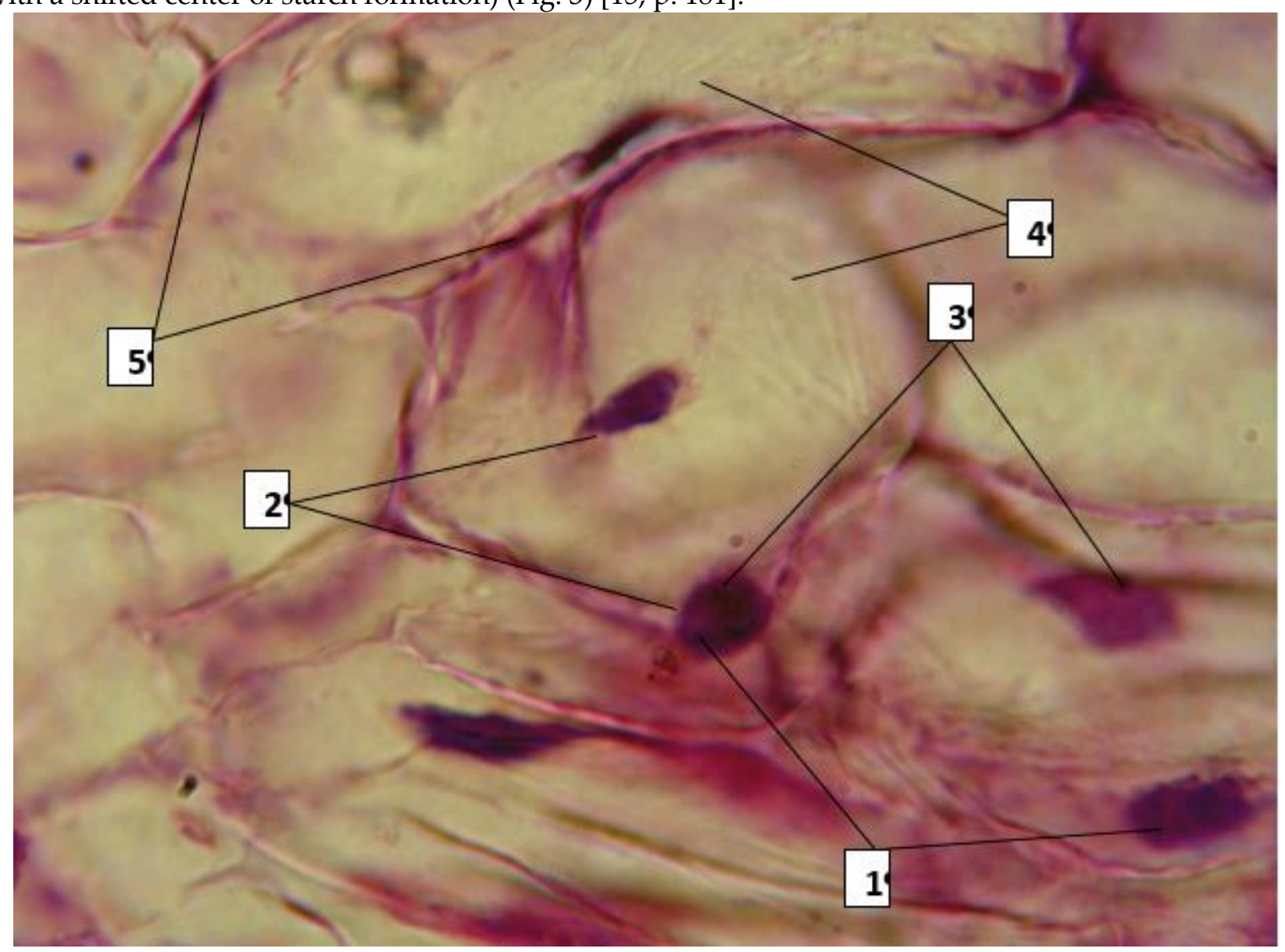

Fig. 3. Mesodermis simple eccentric starch grain of Polygonatum multiflorum (L.) All. rhizome (Microphoto. Mag.: $x$ 1000): 1 - simple eccentric grain of starch; 2 - amyloplast membrane; 3 - center of starch formation; 4 - mesodermis;

\section{5 - thickened cell membrane of the mesodermis.}

Endodermis is the inner layer of the cortex, which performs support and permeation functions. In Polygonatum species the endodermis consists of a single layer of cells in which the radial and inner tangential membranes are thicken, cork, and later become woody. These thickenings look like horseshoes and are called Casparian strip. There are alive, thin-walled cells among the cells with thickened membranes. These cells are situated opposite the xylem rays in endodermis. They are called passage cells. Water and minerals arrive to the stele through them. The cytoplasm of passage cells is characterized by selective permeability. The central cylinder (stele) occupies the axial part of the rhizome of Polygonatum species. It consists of a xylem, a phloem and a peripheral ring of a pericycle. The pericycle consists of one row of alive parenchymal cells marked by meristematic activity. In the central part of the stele xylem forms radial protrusions. Sections of the phloem lie between xylem. And they form a radial vascular bundle (Fig. 4). In Polygonatum species the leading bundle is polyarchic because it contains of more than five xylem sections. 


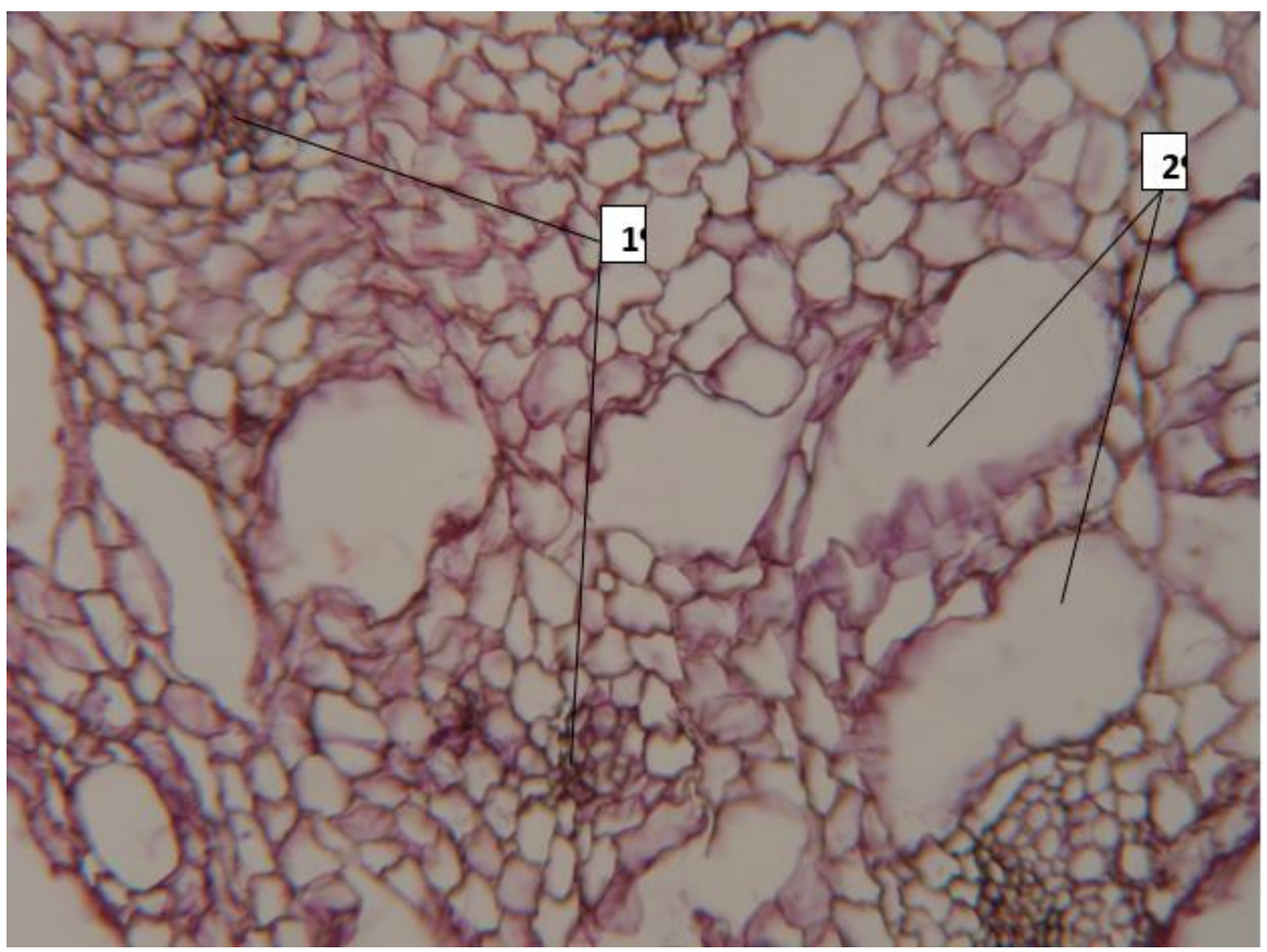

Fig. 4. Centrophloem type of vascular bunches of Polygonatum multiflorum (L.) All. rhizome (Microphoto. Mag.: x 1000): 1 - phloem; 2 - xylem.

A specific feature of Polygonatum multiflorum (L.) All. is the presence of simple aleurone (protein) grains, which consist of a protein membrane and an amorphous protein (Fig. 5) [16, p. 208].

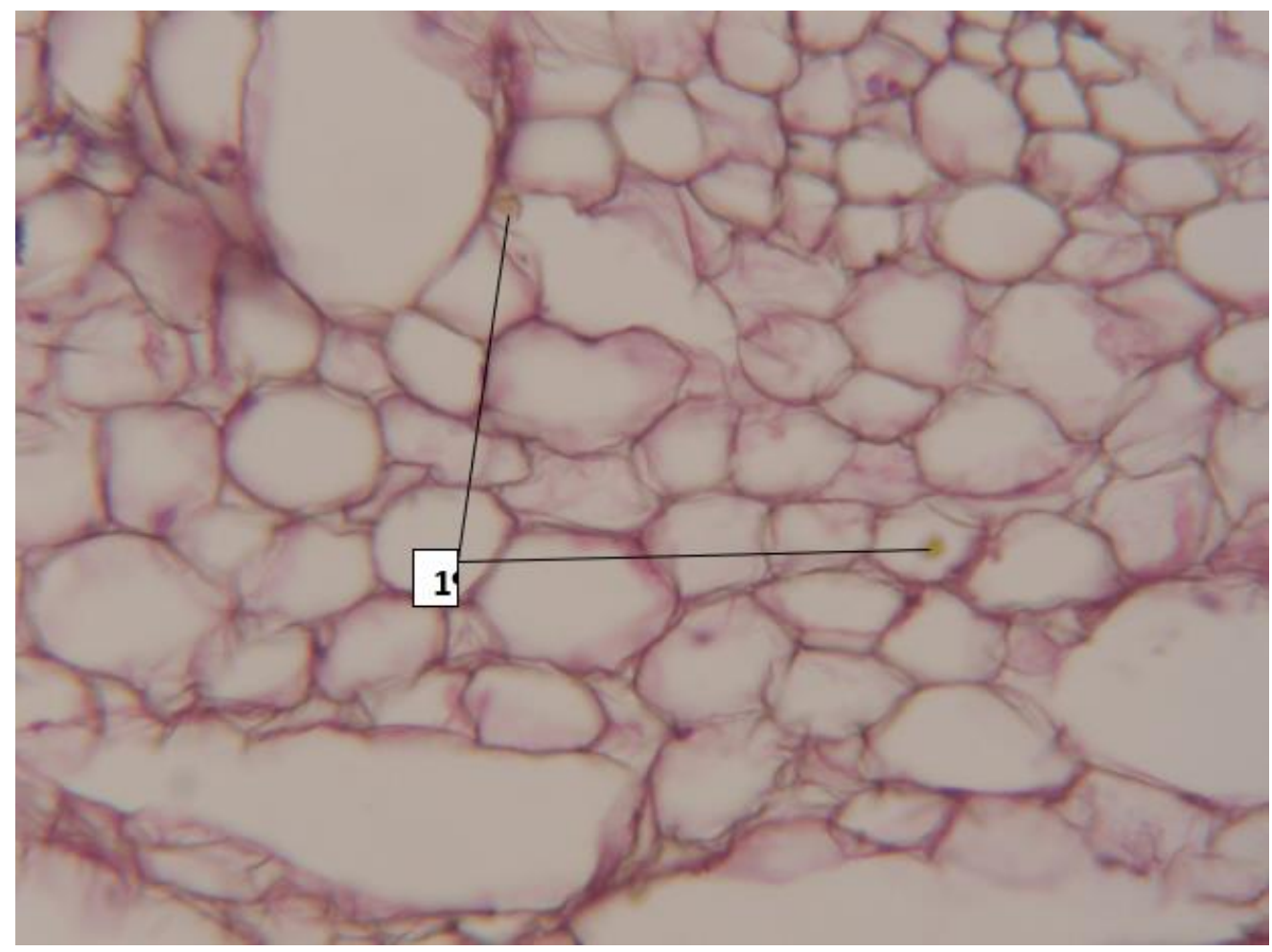

Fig. 5. Aleurone grains in the mesodermis of Polygonatum multiflorum (L.) All. rhizome. (Microphoto. Mag.: $x$ 1000. Staining with Lugol's solution): 1 - aleurone grains. 
As a result of histochemical analysis on the micropreparation of Polygonatum multiflorum (L.) All. rhizome secondary metabolites were detected - drops of fatty oil, the most energy-intensive store substances (Fig. 6). Unlike essential oils, they are less fragrant and non-volatile [16, p. 208].

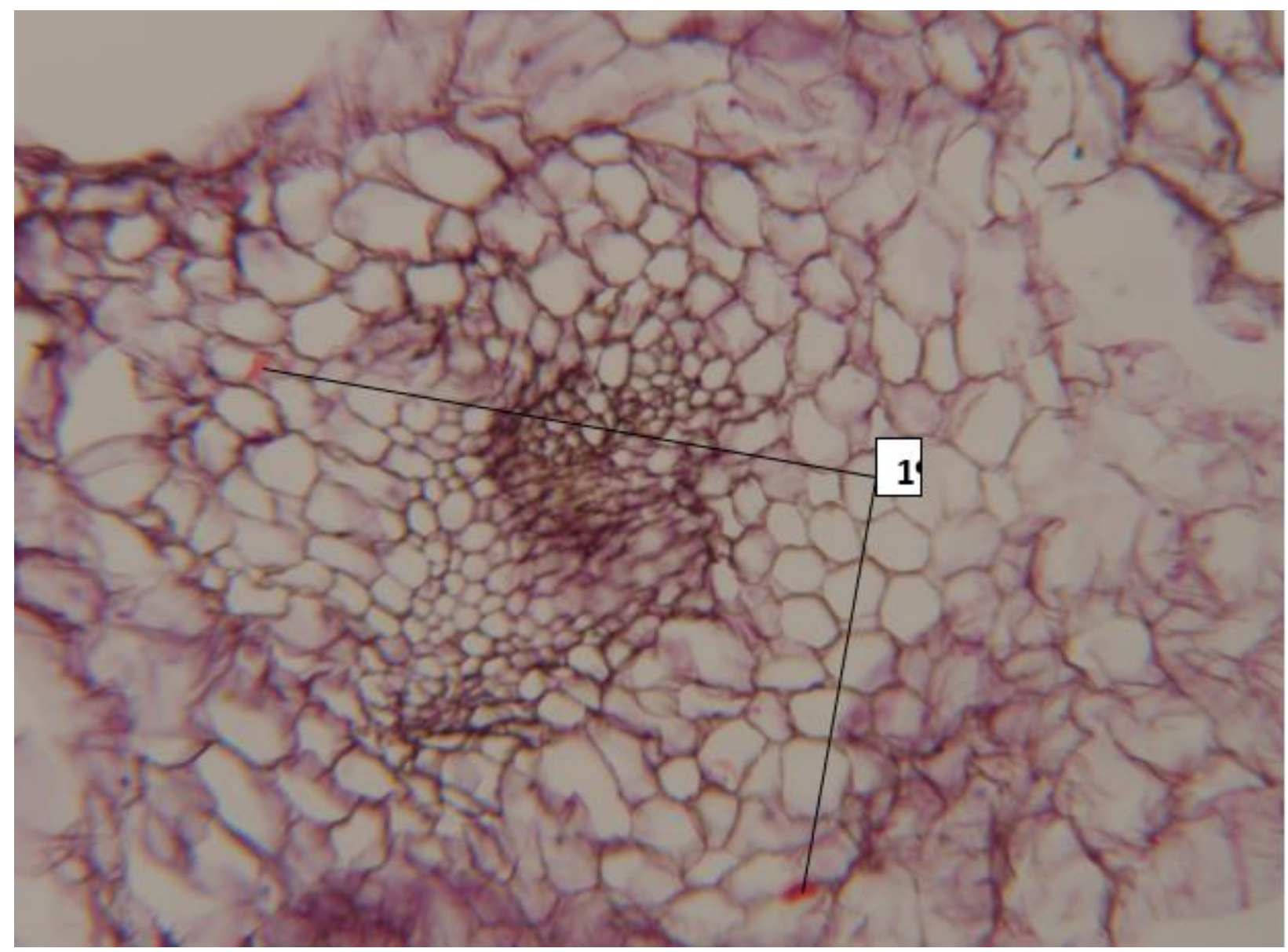

Fig. 6. Drops of fatty oil in the mesodermis of Polygonatum multiflorum (L.) All. rhizome (Microphoto. Mag.: $x$ 1000. Staining by Sudan III): 1 - drops of fatty oil.

\subsection{ANATOMical STRUCTURE OF THE STEM OF POLYGONATUM SPECIES}

In the primary growth of the stem, as well as rhizomes, there is the central cylinder (stele) and the cortex. But in the rhizome, the central cylinder is several times smaller than the cortex. In the stem, the bulk belongs to the central cylinder, and the cortex is represented by a relatively thin layer.

The stem undergoing primary growth shows that all parts are formed from the primary tissue procambia (Fig. 7). The epidermis covering the stem is thin, single-layered. Its cells are alive, tightly closed, covered with cuticle. Among the cells of the epidermis are the guard cells of the stomata. 


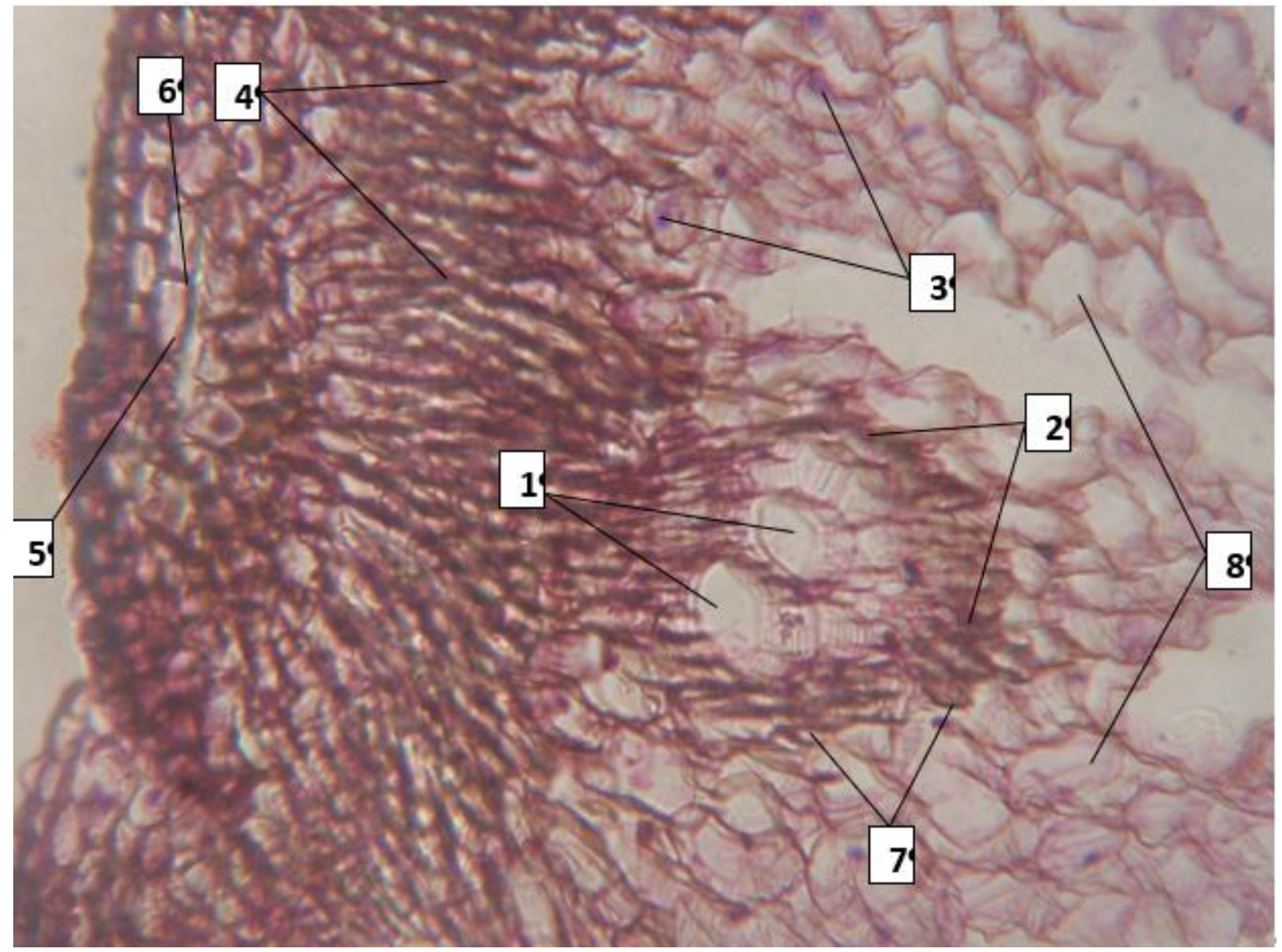

Fig. 7. Vascular stem bundles of Polygonatum multiflorum (L.) All. (Microphoto. Mag.: $x$ 1000); 1 - xylem of the closed collateral bundle; 2 - phloem of the closed collateral bundle; 3 - grains of starch; 4 - pericyclic sclerenchyma; 5 parenchyma; 6 -epidermis; 7 - sclerenchyma; 8 - the ground tissue of the central cylinder.

Cortex of Polygonatum species consists of 2-3 layers of chlorophyll-bearing parenchyma. The central cylinder is characterized by the absence of secondary meristems - cambium and phylogen and the presence of collateral and closed bundles. The central cylinder begins with a fairly thick layer of sclerenchyma of pericyclic origin, which completely envelops the stem. Sclerenchyma cells have uniformly thickened woody membranes (Fig. 8). 


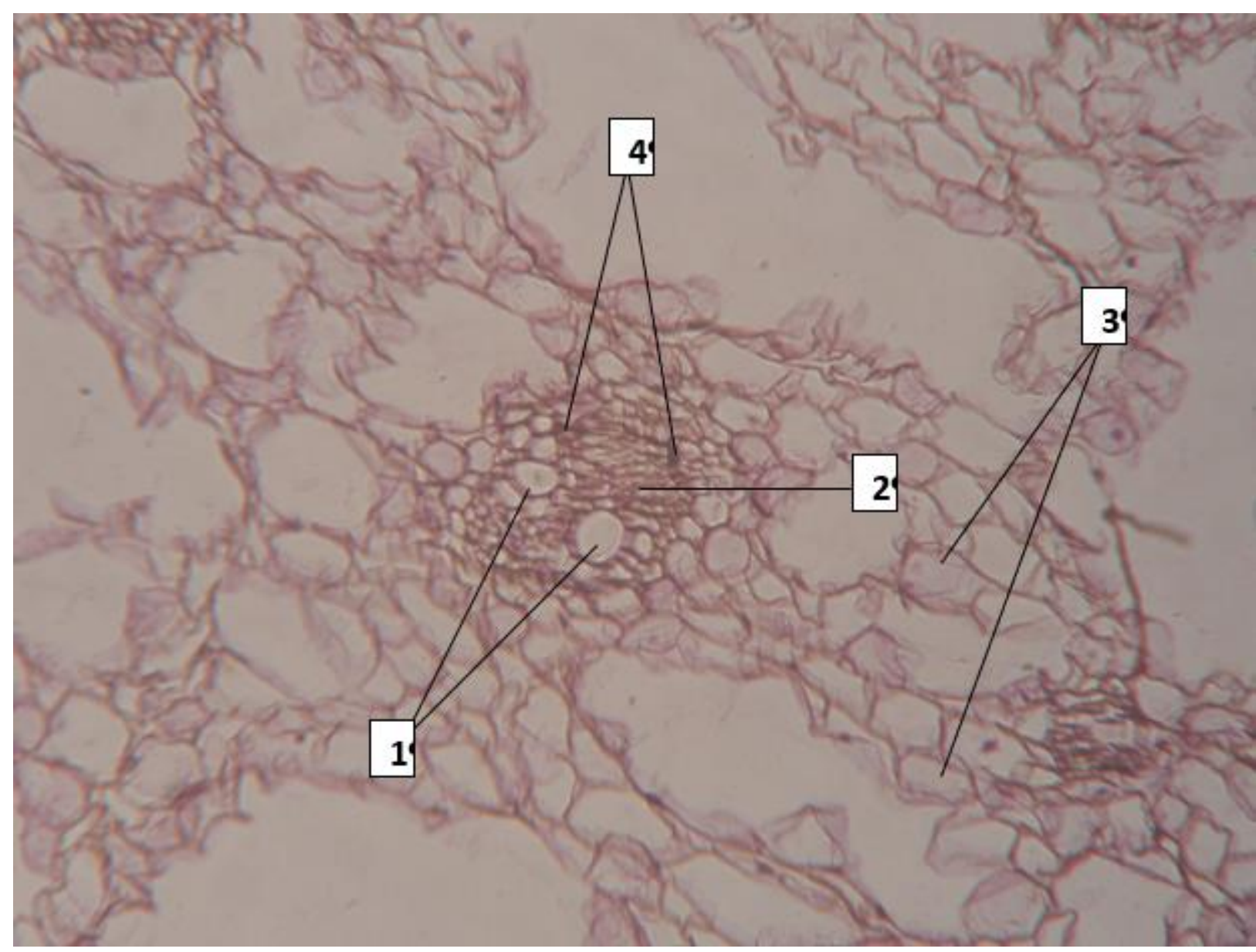

Fig. 8. Vascular elements of Polygonatum multiflorum (L.) All. stem. (Microphoto. Mag.: $x$ 1000); 1 - xylem of the closed collateral bundle; 2 - phloem of the closed collateral bundle; 3 - ground tissue; 4 - sclerenchymatous fibre - bundle sheath.

The ground tissue is behind the sclerenchyma. Many vascular bundles are scattered in the ground tissue. Vascular bundles lie towards the center are large in size and-less in number. Vascular bundles situated towards the periphery are small in size but more in number. Each vascular bundle is conjoint, collateral and closed. That is, they do not contain cambium. Phloem consists of sieve tube elements and companion cells and is always directed to the periphery. Xylem consists of vessels and tracheids and is always directed to the center. As can be seen from Fig. 9 sieve tubes are already formed because the companion cells are of elongated shape, and are tightly adjacent to one side of the sieve tube. Vessels have spiral thickenings (Fig. 10). The bundles do not have a sclerenchymatous fibre (bundle sheath), especially the outer ones, so they are vaguely separated from the ground tissue. 


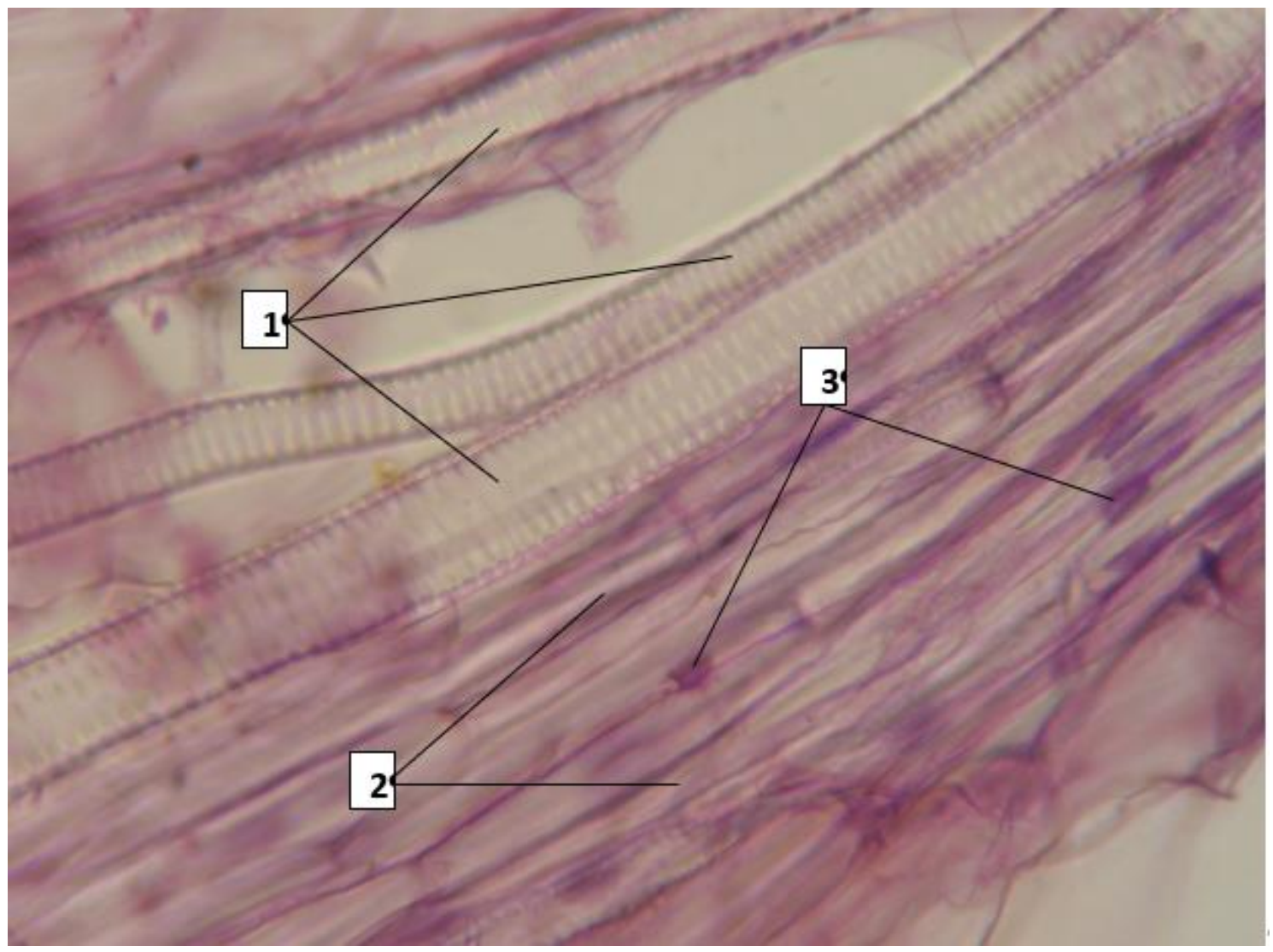

Fig. 9. Phloem elements of Polygonatum multiflorum (L.) All. stem (Microphoto. Mag.: x 1000); 1 - spiral vessel; 2 sieve tube; 3 - companion cell.

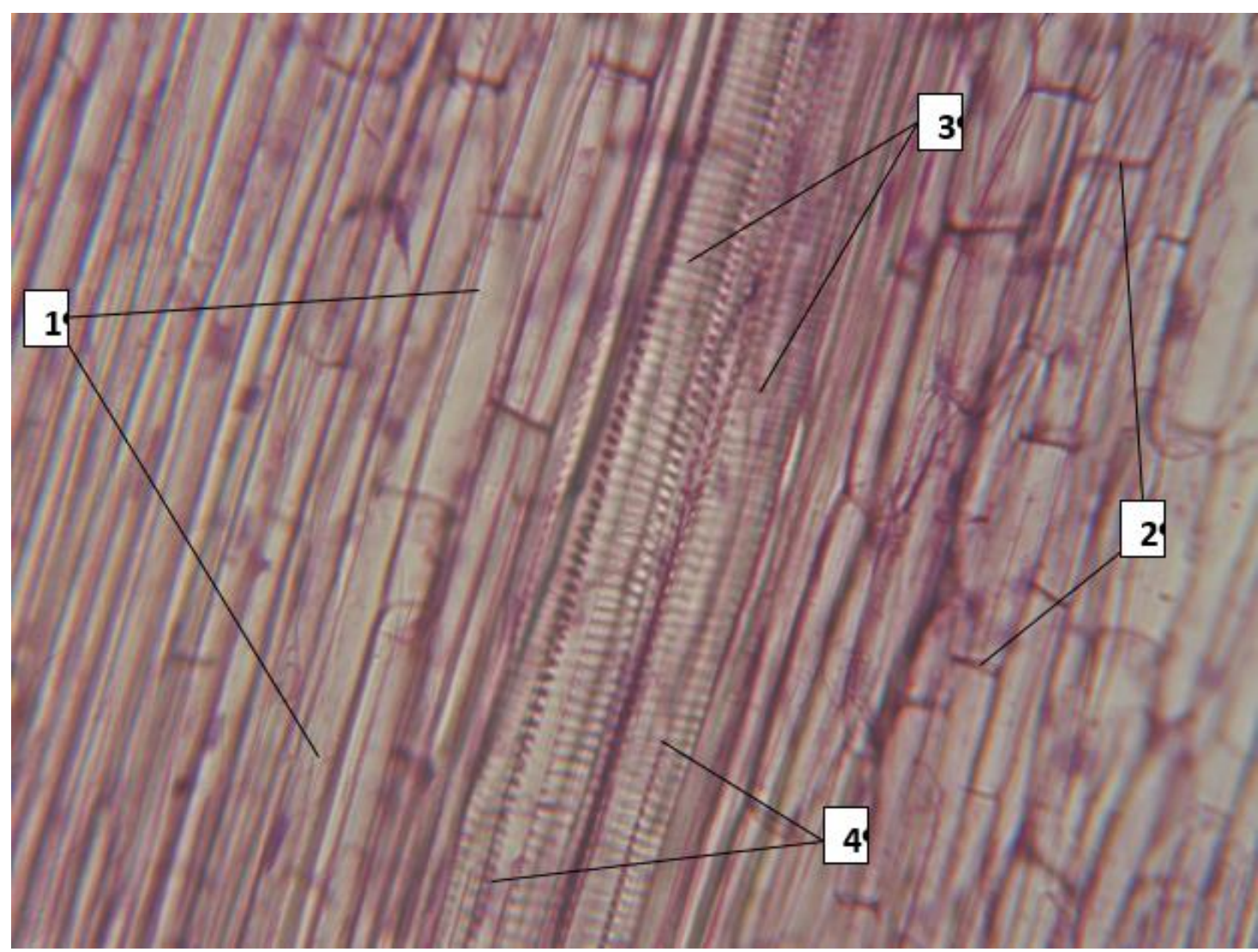

Fig. 10. Xylem elements of Polygonatum multiflorum (L.) All. stem. (Microphoto. Mag.: $x$ 1000); 1 - sieve tube with companion cells; 2 - sieve plates; 3 - spiral tracheid; 4 - spiral thickenings. 


\subsection{AnAtomical STRUCTURe Of THE LeAf of Polygonatum SPECIES}

The leaves of Polygonatum species are oblong or elliptical, slightly narrowed at the base, glabrous with short petioles, green above, grayish-green below, $10-11 \mathrm{~cm}$ long, $4-4.5 \mathrm{~cm}$ wide. The structure of the leaf blade is related to the performance of basic functions: photosynthesis, respiration and transpiration. The leaves are isolateral with a lighter adaxial and shaded abaxial sides (Fig. 11).

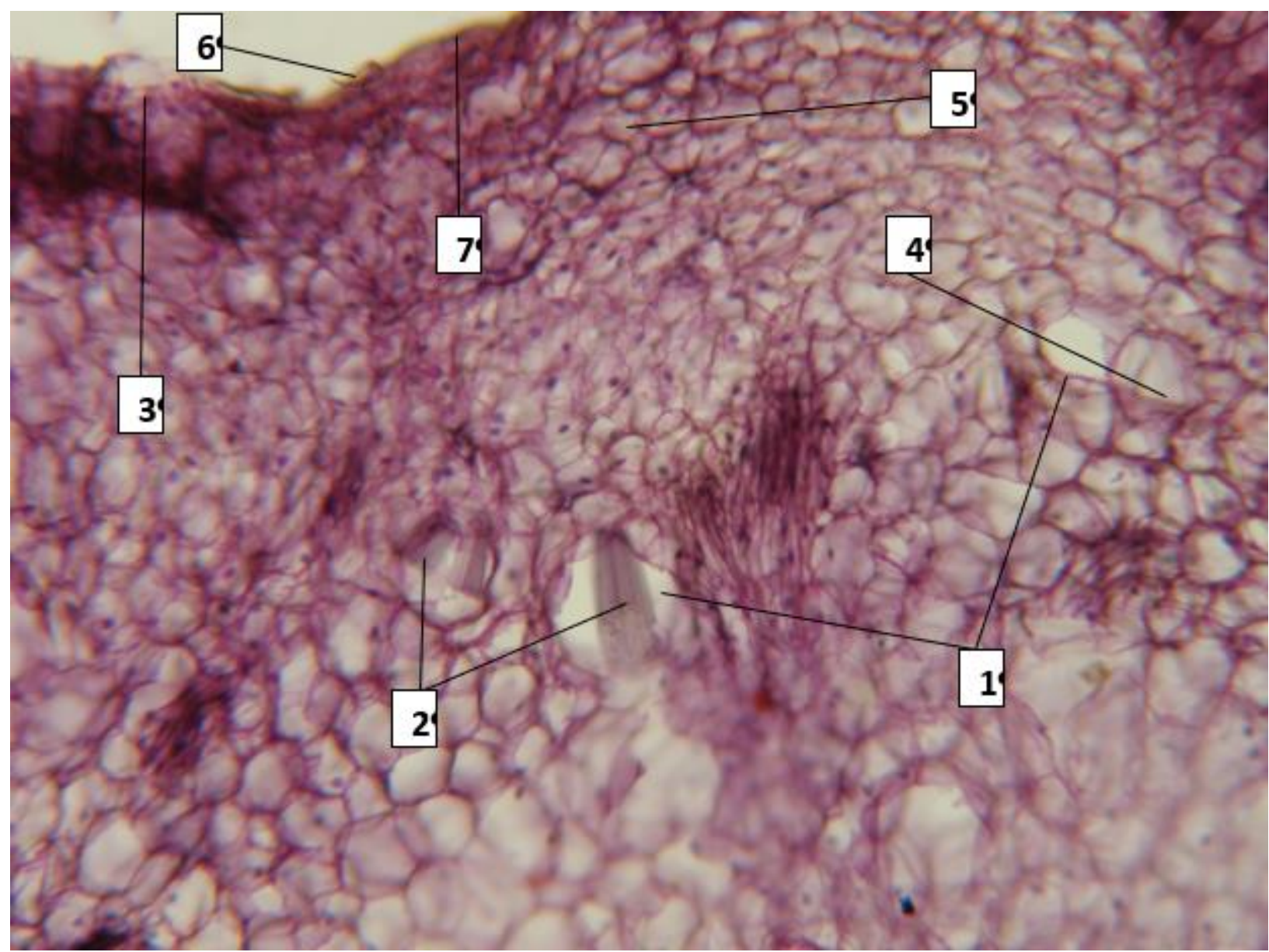

Fig. 11 Anatomical structure of Polygonatum multiflorum (L.) All. leaf blade (Microphoto. Mag.: $x$ 1000); 1 - idioblastic cell; 2 - raffides (dihydrate); 3 - adaxial epidermis; 4 - the main collenchyma (loose); 5 - spongy mesophile; 6 - covering hookshaped trichoma; 7 - cuticle.

The leaf is covered with epidermis, on the outer wall of the cells of which there is a thin layer of cuticle. The chlorenchyma is beneath the epidermis. It makes up the leaf pulp - the mesophyll. On the axial surface of the leaf there are hook-shaped trichomes. The stomata are amonocytic (cells around the guard cells do not differ from the basal ones) and situated only in the abaxial epidermis (hypostomic leaf).

In studied species large crystalline idioblastic cells are located in the mesophyll. Inside these cells are raffids and styloids, which are dihydrates (Fig. 12). Rafids - needle-like crystals lying in a cluster. In the case of mesophyll damage, the membrane of the idioblast ruptures and the crystals fall out, fall apart. Styloids are elongated, narrow, prismatic crystals, with pointed ends. Rafids and styloids are varieties of calcium oxalate crystals (calcium salt of oxalic acid). It accumulates in vacuoles in the form of crystal hydrates of a certain shape and depends on the number of molecules of water of crystallization, which is the end product of metabolism. 


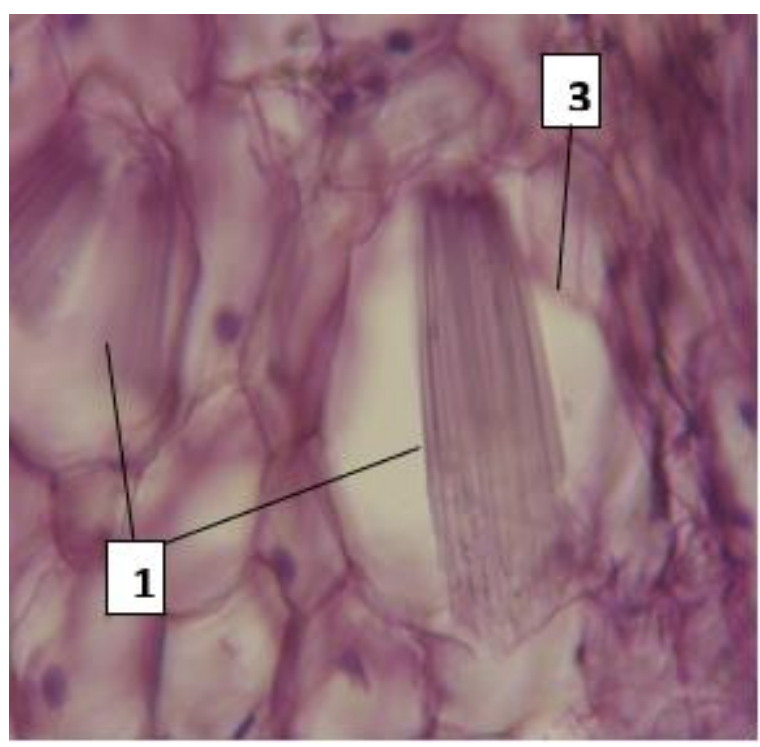

A

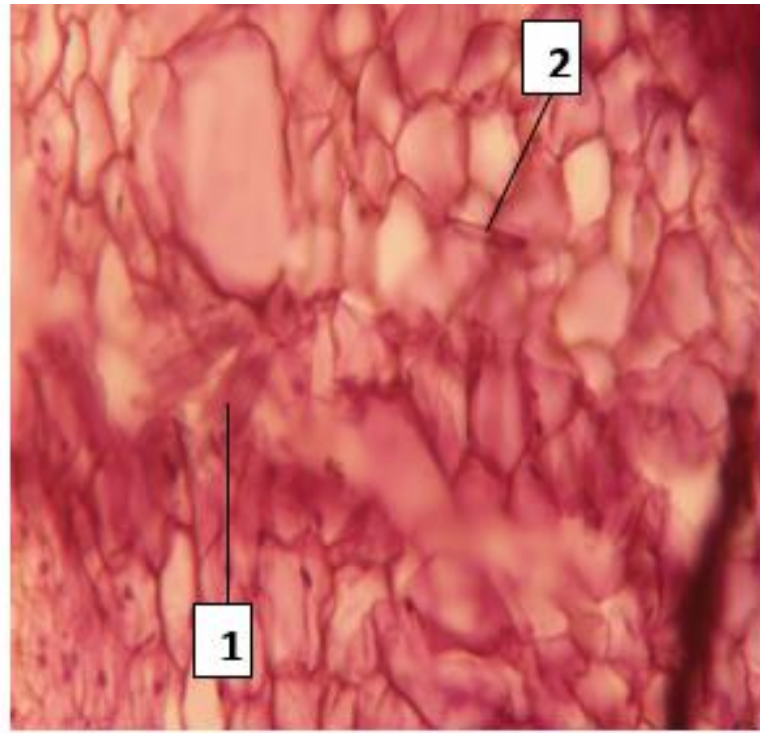

B

Fig. 12. Inclusions in leaf mesophyll of Polygonatum multiflorum (L.) All. (Microphoto. Mag.: x 1000); A - idioblastic cell; B - types of calcium oxalate: 1 - raffides, 2 - styloid, 3 - idioblast membrane.

Mesophyll of the leaf is permeated by a network of veins (Fig. 13), consisting of one or more tightly connected collateral vascular bundles. The cambium functions only in the central vein during the growth of the leaf blade. As the veins branch and approach the top of the leaf, they first disappear mechanical elements, then sieve tubes and vessels. The small marginal veins end in spiral tracheids, which are tightly surrounded by mesophyll cells.

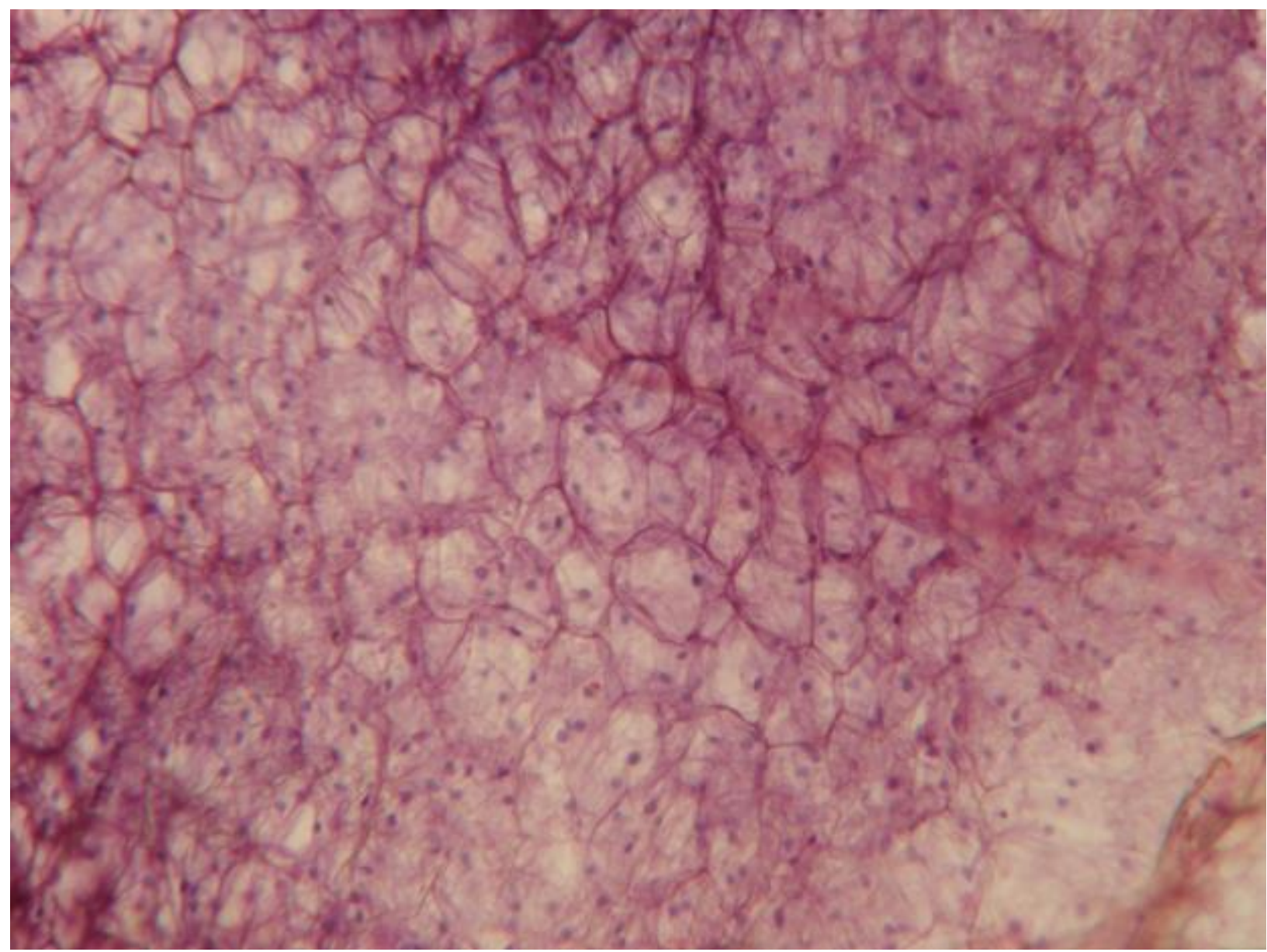

Fig. 13. Loose mesophyll of Polygonatum multiflorum (L.) All. leaf with thickened and distinct membranes (Microphoto. Mag.: x 1000). 
Under the influence of intense light leaf blade of studied species are characterized by greater thickness and rigidity. The veins in the mesophyll are thin, located more densely, the walls of epidermal cells are strongly thickened and have a thick cuticle.

\section{CONCLUSIONS}

The studied species of Polygonatum Mill. have rhizomes of the sympodial type. They are formed by the germination of an underground shoot. At the same time, an apical bud is laid on the shoot, which grows upwards, reaches the soil surface and develops into an aboveground part. A new underground shoot is formed from the nearest lateral bud. Rhizomes of studied species have a primary anatomical structure. Specific feature of Polygonatum multiflorum (L.) All. is the presence of simple aleurone (protein) grains, which consist of a protein membrane and an amorphous protein. Histochemical analysis of the Polygonatum multiflorum (L.) All. rhizome shows the presence of secondary metabolites lipid droplets, the most energy-intensive store substances. Unlike essential oils, they are less fragrant and non-volatile.

In the primary structure of the studied species stems, as well as rhizomes, there is the central cylinder (stele) and the cortex. But in the rhizome, the central cylinder occupies several times less volume than the cortex. In the stem, most of it belongs to the central cylinder, and the cortex is represented by a relatively thin layer. The studied species of the Polygonatum Mill. genus have a primary anatomical structure of the stem. All parts are formed from the primary meristematic tissue procambia.

The leaves of Polygonatum species are oblong or elliptical, slightly narrowed at the base, glabrous with short petioles, green above, grayish-green below, $10-11 \mathrm{~cm}$ long and $4-4.5 \mathrm{~cm}$ wide. The structure of the leaf blade is related to the performance of basic functions: photosynthesis, respiration and transpiration. The leaves are isolateral with a lighter adaxial and shaded abaxial sides.

\section{REFERENCES}

[1] Mordak E. V. Liliaceae family. Plant life, V.6. Moscow, Prosveshchenie, 1982. (in Russian)

[2] Nechytailo V.A., Kucheriava L.F. Botany. Higher plants. Kyiv, Fitosotsiotsentr, 2000. (in Ukrainian)

[3] Gubanov I.A., Novikov V.S., Tihomirov V.N. Determinant of higher plants of the middle strip of the European part of the USSR. Moscow, Prosveshchenie, 1981. (in Russian)

[4] Barbarych A.I., Bradis Je. M., Vernychenko Yu. V. Determinant of Ukrainian Carpathians' plants. Kyiv, Naukova dumka, 1977. (in Ukrainian)

[5] The Plant List. Available at: http://www.theplantlist.org/tpl1.1/record/kew-284008.

[6] Angiosperm Phylogeny Group. An update of the Angiosperm Phylogeny Group classification for the orders and families of flowering plants: APG IV. Botanical Journal of the Linnean Society, 181 (1) (2016), 1-20. doi:10.1111/boj.12385

[7] Mucina L. Conspectus of classes of European vegetation. Folia Geobot. Phytotax, 32 (2) (1997), 117 - 172.

[8] Niklfeld H. Aspects of mapping regional flora. In: Mapping the Flora of the Balkan peninsula. Sophia, Bulg. Acad. of Saensis, 1981.

[9] Oberdorfer E. Pflanzensoziologische Excursions Flora. Stuttgart, Verlag E. Ulmer, 1979.

[10] Didukh Ya.P. Ecoflora of Ukraine, V.2. Kyiv, Fitosotsiotsentr, 2004. (in Ukrainian)

[11] Dobrochaeva D.N. et al. Determinant of higher plants of Ukraine. Kyiv, Fitisociotsentr, 1999. (in Russian)

[12] Minarchenko V.M., Tymchenko I.A., Solomakha T.D. Medicinal plants of Precarpathian region: resource and medical significance. Visnyk Chernivetskogo med. Instytutu, 2 (4) (2005), 8-15. (in Ukrainian) 
[13] Gontova T.M. et al. Anatomy and morphology of plants in figures. Kharkiv, NFaU, 2014. (in Ukrainian)

[14] Grygora I.M. et al. Botany. Workshop. Kyiv, Vydavnychyi stentr NAU, 2004. (in Ukrainian)

[15] Serbin A.G. et al. Pharmaceutical botany. Vinnytsia, Nova knyga, 2007. (in Ukrainian)

Address: Nadia Riznychuk, Victoria Gniezdilova, Vasyl Stefanyk Precarpathian National University, 57 Shevchenko St., Ivano- Frankivsk 76018, Ukraine.

E-mail: nadiia.riznychuk@pnu.edu.ua; viktoria.gniezdilova@pnu.edu.ua.

Received: 10.11.2020; revised: 25.12.2020.

Різничук Надія, Гнезділова Вікторія. Анатомічні особливості будови видів роду Polygonatum Mill. на Передкарпатті. Журнал Прикарпатського університету імені Василя Стефаника, 7 (4) (2020), 53-65.

Види роду Polygonatum Mill. мають кореневища симподіального типу. Вони утворюються за рахунок проростаючого підземного пагона. Одночасно на пагоні закдадається верхівкова брунька, яка росте вгору, виходить на поверхню грунту і розвивається в надземну частину. А новий підземний пагін формується з ближчої бічної бруньки. Кореневища видів роду купина мають первинну анатомічну будову. Видоспецифічною ознакою Polygonatum multiflorum (L.) All. є наявність простих алейронових (протеїнових) зерен, які складаються з білкової оболонки та аморфного білка. При гістохімічному аналізі на мікропрепараті кореневища Polygonatum multiflorum (L.) All. було виявлено вторинні метаболіти - краплі жирної олії, найбільш енергоємкі запасні речовини. На відміну від ефірних олій, вони менш ароматні та нелеткі. У первинній будові стебла, як і кореневища, видів роду Polygonatum Mill. виділяють центральний циліндр та первинну кору. Але у кореневищі центральний циліндр займає в кілька разів менший об'єм, ніж первинна кора. У стеблі ж основна маса належить центральному циліндру, а первинна кора представлена порівняно тонким шаром.

Анатомічна будова стебла видів роду купина Polygonatum Mill. первинна, пучкового типу, тобто всі частини утворюються з первинної твірної тканини - прокамбію. Листки видів роду Polygonatum Mill. довгасті або еліптичні, біля основи трохи звужені, голі з короткими черешками, зверху зелені, знизу сірувато-зеленуваті, 10-11 см завдовжки, 4-4,5 см завширшки. Будова листкової пластинки пов'язана із виконанням основних функцій: фотосинтез, дихання i транспірація. Анатомічна організація листка видів роду Polygonatum Mill. ізолатерального типу з більш освітленою адаксіальною і затіненою абаксіальною сторонами. Мезофіл дистка пронизаний мережею жилок, що складається з одного або декількох щільно з'єднаних колатеральних судинно-волокнистих пучків. Камбій міститься лише в центральній жилці, що зумовлюе їі потовщення.

Кдючові слова: анатомія, Polygonatum Mill., кореневище, стебло, дисток. 